\title{
Contrastive-Comparative Study of Infinitives in English and Tatar
}

\author{
Alsu Yu. Giniyatullina ${ }^{1}$, Milyausha R. Garaeva ${ }^{1} \&$ Rozaliya A. Karimova ${ }^{1}$ \\ ${ }^{1}$ Kazan (Volga Region) Federal University, Kazan, Russia \\ Correspondence: Alsu Yu. Giniyatullina, Kazan, Kremlyovskaya Street, 18, 420008, Russia. E-mail: \\ ramil.giniyatullin@mail.ru
}

Received: June 2, 2015 Accepted: June 15, 2015 Online Published: June 29, 2015

doi:10.5539/jsd.v8n5p141

URL: http://dx.doi.org/10.5539/jsd.v8n5p141

\begin{abstract}
The present study is devoted to investigation on English and Tatar infinitive. The study is significant due to the fact that the interest to contrastive-comparative study of languages has amplified. It is caused by aspiration to reveal common features and tendencies, characteristics, uniqueness and originality of each language. The present study aims to investigate and identify similarities and differences between infinitives in both languages in terms of morphological and syntactical structures. The study is descriptive, contrastive and comparative. It compares, contrasts, and describes grammatical structures of English and Tatar Infinitives. The results of the study can be used in pedagogical grammar, and at the same time, in developing materials for EFL learners, integrating L1 grammar into teaching L2, which can be a facilitative factor to raise the learners' awareness.
\end{abstract}

Keywords: contrastive linguistics, grammar, morphology, English Infinitive, Tatar Infinitive

\section{Introduction}

The problem of infinitive and infinitive constructions started attracting the attention of linguists many years ago. It is also important in Modern Linguistics and is within the view of many researchers. A. M. Konyashkin (2000), O. M. Chupasheva (1999), V. M. Glukhih (2002), M. M. Guhman (1968), A. I. Moiseev (1952), A. A. Potebnya (1958), V. V. Vinogradov $(1960,1972)$ have made a significant contribution to the study of the issue. The subject is also analyzed in the works of such researchers as A. A. Shakhmatov (1941), K. A. Admony $(1955,1964)$, Ramazanova D.B. (1974), M. Z. Zakiyev (1992), O. N. Zhuravleva (1999, 2001), Khisamova V. N. (2004), Gatiyatullina Z. Z. (1984), Bairamova L. K. (1994), Salekhova N. Kh. (1984), Tumasheva D. G. (1986).

The present study is significant due to the fact that non-finite form of the verb, the infinitive is analyzed in English and Tatar languages. A verb takes a special place in the system of language, as it has unique characteristics, not found in other parts of speech. Secondly, infinitive cannot be used as the predicate in the sentence, since it expresses an action without denoting a person or the category of number. Thirdly, until present it is still debatable whether infinitive belongs to a certain part of speech, or it forms a special, independent group.

The study is also significant because the results of it can be used in pedagogical grammar, and at the same time, in developing materials for EFL learners, integrating L1 grammar into teaching L2, which can be a facilitative factor to raise the learners' awareness. Teaching a foreign language with the help of the native language of the learner will help to avoid interference of the Tatar language and prevent mistakes in the forms of the verbs. The most interesting are the cases when there are differences of certain grammatical categories in the two languages compared and contrasted and at the same time similarities between them. That's why it is necessary to make well organized and circumspect corrections which should vary in form and content. Such correction can be made on all levels of teaching a foreign language. (Khisamova, 2004)

The English and Tatar languages are not genetically related. Tatar belongs to agglutinative languages in terms of structural typology; English is an inflective-analytical language.

Until present there has not been done any research in contrastive-comparative study of infinitive in either of the languages.

According to L.S. Barkhudarov, infinitive is a non-finite form of the verb, as it does not have any person forms. Unlike finite forms of the verb, which are often used in the function of a predicate in the sentence, non-finite forms of the verb may perform various syntactic functions, except simple predicate (Barkhudarov, 1966).

Non-finite forms of the verb suggest avoiding complicated subordinate clauses and using short compact 
expressions. Infinitive in the English language, as well as in Tatar partially has grammatical features of the verb. In the Tatar language, infinitive has the category of voice, can take the formant of aspect, the formant of frequency; but it does not have the categories of tense and mood.

The purpose of the present study is to identify morphological features of infinitive in the English and Tatar languages.

The following objectives have been set:

1) To consider and analyze theoretical and scientific information on the morphology of the English and Tatar languages;

2) To examine grammatical categories of infinitive in English and Tatar;

3) To study morphological and syntactic features of infinitive;

The objectives suggest a set of methods to be used in the present study: the method of analysis, a descriptive method, and the methods of generalization, comparison, contrast and classification.

\section{Methodological Framework}

\subsection{Infinitive in the Verbal System of the English Language}

English infinitive combines in itself the features of a noun and a verb, at the same time it has its own peculiar morphological and syntactic features. A common feature of the infinitive and the noun is the same syntactic functions in the sentence. Common features of the infinitive and the verb are that it has the category of aspect (Continuous, Indefinite, Perfect and Perfect Continuous), voice (Active, Passive), it takes dependent words and can be modified by an adverb.

The formal marker of the infinitive in English is the particle to, which does not have any semantic meaning. For example, (to) read, (to) be, (to) watch, (to) look, (to) listen.

To- infinitive is used in the following cases:

1) To express purpose: She opened her purse to see if there was any money left (A. Chrisie)

2) In some cases in speech the particle to can express the infinitive itself after such verbs as to like, to ask, to forget, to try, to mean, to promise, to wish, to refuse, to want, to be going, would like/love to, to be glad, to be allowed and others:

I don't want to do this just because you tell me to. Why didn't you tell me this yesterday?

I meant to, but I didn't have time.

3) After such adjectives as angry, happy, glad, sorry and some others:

I am happy to have talked to her.

4) After question words where, how, what, which, who, except question word why:

Do you know how to get to the center of the city?

5) After would like, would love, would prefer:

We would like to spend another week here.

6) After nouns:

It is a great pleasure to see you again.

7) After constructions with too and enough:

There is enough food to feed the whole army!

He is too young to understand this.

8) After constructions $i t+b e+a d j$.:

It was so kind of you to offer me your help.

9) After be+ the first (the second/ next/ last/ best etc.):

He was the first to open his present.

10) In such set expressions as to tell the truth, to begin with, to be honest and some others:

To tell you the truth, I don 't trust her. 
In some cases, particle to can be omitted. Such infinitive is called "bare infinitive", it is used with the verbs of sense perception.

Besides, infinitive itself can be a part of compound predicate and is considered to be the initial form of the verb, and the bare infinitive is used in dictionary entries.

Bare infinitive is used in the following cases:

1) After modal verbs and auxiliary verbs: must, may, can, could, will/ shall, would, need and dare.

My sister can swim very well.

I need to see her.

We must respect our parents.

Shall I talk to her? The modal verbs be (to), have (to) u ought (to) are exceptions:

We are to respect his point of view.

2) After had better and would rather: I would rather go by train. You would rather consult the doctor tomorrow.

She had better take umbrella with her.

3) In complex object after the following verbs:

a) To see, to hear, to feel, to notice and others: I saw her cry.

b) To make, to let: What made you leave? But, it should be remembered that if the verb of the sentence is in the Passive voice, to-infinitive is used: Children are made to go to school every day. I was made to learn this rule by heart even if I didn't want to.

c) To help can take either to-infinitive or bare infinitive: Excuse me, can you help me (to) carry my luggage?

4) After verb to know in the Passive voice, to-infinitive is used in Modern English: He is known to be a very wise man (A. Christie)

5) In the questions which begin with why not: Why not go for a walk?

6) With the verbs of sense perception: feel, see, watch, hear и smell: - I saw your run across the street. I heard he slammed the door. She felt her cold chills.

7) If two infinitives are used together linked with and or or, then the particle to before the second is usually omitted: I would like to invite him to our place and show him the painting.

It is important to note that our perception can be full (when we see the whole process or the action from its start to its end), and partial (when we manage to see a certain moment of an action or process).

For example, while having tea, we see how the sister takes the cup, slowly drinks tea, and puts the empty cup onto the saucer. In this case bare infinitive is used: I saw my sister drink tea.

But if we did not see the whole process, if we just peeped into the kitchen and noticed that the sister was having tea at the moment, then not the infinitive but the gerund is used: I saw my sister drinking tea.

\subsection{Infinitive in the Verbal System of the Tatar Language}

There are four non-finite forms of the verb in English: infinitive (to take), gerund (taking), participle I (taking), participle II (taken). These forms possess some verbal and some non-verbal features. The main verbal feature of infinitive is that it can be used as part of analytical verbal forms (have come, will do, etc.) Thus, in the modern Tatar language there are four non-finite forms of the verb as well. They are: infinitive (атарга), participles (атылган), adverbial participle (килеп) and noun of action (ату).

Infinitive is a multifunctional and polysemantic category, which occupies an intermediate position between the noun and the verb. Infinitive in the Tatar language is formed by the general structural formula, according to Professor K.G. Ishbaev, this form of the infinitive is common for the majority of Turkic languages: Tatar, Bashkir, Altai, Khakass and others.

Lexically non-finites do not differ from finite forms. Grammatically the difference between the two types of the forms lies in the fact that non-finites may denote a secondary action or a process related to that is expressed by the finite verb.

Infinitive is a non-finite form of the verb, which denotes an action without reference to the subject. Infinitive possesses the verb categories of voice, completeness, and aspect. They lack the categories of person, number, mood, and tense. 
The main function of infinitive is to express the purpose of the action, which is most often achieved in combinations of infinitives and action verbs.

The formal marker of infinitive in English is pre-infinitive particle to, which distinguishes it from homonymous finite forms of the verb, while the formal marker of the Infinitive in Tatar is the affix -blpza, which is formed from the participle ending on - bip with the affix -za. Form with - ырга has the following variants - ергә, -рга / -ргд, -арга /-әргә.

Table 1. The formal markers of infinitive in English and Tatar

\begin{tabular}{ll}
\hline English & Tatar \\
\hline To play & Уйнарга (uinarga) \\
To knit & Бәйләргә (bəilərgə) \\
To know & Белергə (belergə) \\
\hline
\end{tabular}

According to D.B. Ramazanova, linguageographical study of Tatar dialects shows that some other forms of the infinitive: -мага /-мәгә and its variants - ма /-мә, -ырга, / - ергә, and гали / - гәле are also widely used.

It is formed by adding affix $-2 a, /-z$ to the participle with the suffix -blp. The -ырга /- epгə can be added to the stem possessing a category of voice (ачылырга- to be opened), multiplicity (ачылгаларга- to be opened from time to time), the negative aspects (ачылмаска- not to be opened), etc. In some dialects of the Tatar language there are also infinitive forms of барма килә and кайтма килә. In the modern Tatar literary language another old form of the infinitive on -ма /-мә, -мага /-мәгә, -маль /-мәле, -маг /-мәr is widespread. (Zakiyev, 1993)

Алия район үздгенд дәу әнисен алмага китте (альрга китте)-Aliya went to the town to take her granny.

In terms of morphology, infinitive in the Tatar language has features of direction (киенергә - to dress), degree (киенә башларга - to start dressing), negative aspect (барырга - бармаска, to go -not to go). In a sentence functioning as a predicate, the Tatar infinitive refers to the noun, which gets particular case forms.

Examples: мәктәпкә барырга -to go to school (Commitative case by John Lyons), мәктәптән кайтырга -come (back) home from school (locative case, by Ch. Fillmore (syntactic-semantic classification)).

The negative form of English Infinitive is formed with the help of the negative particle not used in pre-position to the Infinitive: not to write, not to be written. The negative form of infinitive in Tatar is formed with the help of affix - маска /-мәскә.

Examples: сайларга - сайламаска (to choose - not to choose), үстерергә -үстермәскә (to grow - not to grow), яшәргә-яшәмәскә (to live - not live), чабарга - чапмаска (to run - not to run), төш-мәскә (not to go down), мен-мәскә (not to go up).

Combination of infinitive with the word түгел, gives a negative meaning: Бу эшне бүтән кешенең ярдәменндн башка эщләрга мөмкин түгел. - It is impossible to do the job without any help.

Unlike the English Infinitive, the following characteristics of Tatar Infinitive can be found: 1) Tatar infinitive can express repeated action with the help of affixes -гала/-гәлә, -кала/-кәлә,-итыр/-штер,-ышштыр/-ештер. Examples: ал-гала-рга (to buy from time to time), сат-кала-рга (to sell from time to time) 2) Tatar infinitive can take an interrogative particle - мы/-ме): Чакырыгамы? (Am I to invite?) 3) Tatar infinitive can have an aspect of uncertainty, expressed with the help of affixes - дыр/-дер, -тыр/-тер: дйтергәдер бит? (Am I to say?)

None of the forms have morphological features of non-verbal parts of speech, nominal, adjectival or adverbial. In the sphere of syntax, however, non-finites possess both verbal and non-verbal features. Their non-verbal character reveals itself in their syntactical functions. Thus, infinitive performs the main syntactic functions of the noun, which are those of a subject, an object and a predicative. They cannot form a predicate by themselves, although unlike non-verbal parts of speech they can function as part of a compound verbal predicate.

Syntactically the verbal character of non-finites is manifested mainly in their combinability. Similarly to finite forms they may be combined with nouns functioning as direct, indirect, or prepositional objects, with adverbs and prepositional phrases used as adverbial modifiers, and with subordinate clauses.

Non-finites may also function as link verbs, combined with nouns, adjectives or statives as predicatives, as in: 
to be/being a doctor (young, afraid).

All non-finite verbs may form the so-called predicative constructions, that is, two-component syntactical units where a noun or a pronoun and a non-finite verb form are in predicative relations similar to those of the subject and the predicate: I heard Jane singing; We waited for the train to pass; I saw him run, etc. In the sentence Tatar infinitive can function as a subject, an object, a predicate, a predicative and an adverbial modifier.

\subsection{Syntactic Functions of English and Tatar Infinitives}

English and Tatar Infinitives both have the following syntactic functions:

\section{1) Subject}

To go on like this was dangerous. (Galsworthy)

Амарга бар әле. - We have something to eat.

2) Unlike Tatar, where the Infinitive can be the predicate of the sentence, in English the Infinitive is used in the function of a predicative (a part of a predicate)

Сиңа барырга! You are to go!

Сугышчыга курыкмаска! A fighter is not to be afraid!

Вәгъдәне үтәрга! - The promise is to be kept!

The Infinitives барырга, курыкмаска, үтәргә are used in the function of a predicate, at the same time, expressing necessity, obligation, and wish.

Tatar infinitive can function as part of a compound predicate.

Почмакка барып басты да жсырларга тотынды (F. Amirkhan). She came up to the corner and started to sing.

English Infinitive may be used in the function of part of a compound verbal predicate in combination with modal verbs, and the verbs to begin, to start, to intend, to decide and others, expressing the beginning, duration, and the end of an action, or the attitude of the doer of the action towards the action expressed by the infinitive.

My watch began to gain; it gained faster and faster day by day. (Twain)

In the sentences containing the Subjective Infinitive Construction English Infinitive may be used as part of a compound verbal predicate.

At least one radioactive isotope is known to exist for all known elements.

Unlike the Tatar language, English Infinitive can be used as a nominal part of a compound predicate.

"I think", he said, "that to prolong this discussion is to waste time." (Galsworthy)

This example presents the Infinitive to waste as a nominal part of a compound predicate.

The Infinitive can be used as part of a Compound Predicate.

Part of a Compound Nominal Predicate: The plan was to go to the dean.

There is an interesting model where both the subject and the predicate are expressed by the Infinitive: To love is to believe. To know is to understand.

Part of a Compound Verbal Modal Predicate: You should have told me about it yesterday.

Part of a Compound Verbal Aspect Predicate: She began to cry.

\section{3) Object}

I have never learnt to read or write. (Collins)

Аюны да биергә өйрәтәләр. - They will teach a bear to dance.

According to the examples above, it becomes clear that English Infinitive in the function of an object has a lexical-semantic equivalence with Tatar Infinitive.

He found it utterly impossible to leave the spot. (Hardy) He asked me to wait a little. They demanded to be shown all the documents.

\section{4) Attribute}

I have nobody to say a kind word to me. (Trollope)

Әмма китәргә вакыт житкәч, карчык уксеп-уксеп елады. (Sh.Kaмal) 
But when it was time to leave, the old woman started weeping

Сыенырга урын эзли башлый.(G.Ibragimov) It begins to look for a place to nestle.

The illustrated examples show that both English and Tatar Infinitives modify a noun that follows it.

I have no desire to go there.

The amount to be paid includes the cost of packing.

The Infinitive used attributively often acquires some modal meaning - the meaning of obligation or that of possibility.

The Infinitive is often used instead of the passive one here.

There is no time to be lost $=$ There is no time to lose.

\section{5) Adverbial modifier}

To reach the lecture hall he had to walk almost half a mile (D.C.)

Урман кисәргә киттеләр. - They left to cut the trees in the wood.

Adverbial modifier of purpose denotes the purpose of the action, Infinitives of the verbs ending in -blp, $-м a c$ are used in this function. (Zakiev, 1992)

The examples present infinitive in the function of an adverbial modifier of purpose. Despite of the English Infinitive, the function of an adverbial modifier of purpose of the Tatar Infinitive is its main function. English Infinitive can function in the sentence as an adverbial modifier of result, adverbial modifier of comparison, adverbial modifier of attendant circumstances.

I remained there (in order) to see what would happen.

To be properly understood this rule must be explained once more.

Adverbial modifier of purpose, often with the conjunctions in order and so as, especially when the meaning is negative: She put on her coat in order not to catch cold.

Adverbial modifier of result after the adverbs too, enough and sufficiently: Molecules are too small to see with an eye.

Adverbial modifier of comparison with conjunctions as if, as though: She began to talk loudly as if to show that she was not upset.

Adverbial modifier of attendant circumstances: An astronaut leaves the Earth and returns fifty years later to find his twin-brother quite an old man while he is still in the prime of his life.

6) English Infinitive can be used as parenthesis - to tell the truth, to begin with, to sum up, etc. To begin with we have not enough money to buy it.

In Tatar, parenthesis may be expressed by infinitives with the verbs кирәк, мөмкин. "әйтергә кирәк”, "әйтергә мөмкин"”, (It should be said)

Бу тору, дйтергә мөмкиндер, кояш, айсыз тору. (G. Tukay)

This life, it should be said, is like life without the sun and the moon. (Zakiev, 1992)

7) When used in the Objective-with-the-Infinitive construction, Infinitive performs the function of part of a Complex Object: I saw him cross the street. When used with the Nominative-with-the-Infinitive construction the Infinitive performs the function of part of the Compound Verbal Modal Predicate of special type (without modal verb): He is sure to be waiting for us.

In this study, the finite verb is considered as a grammatical and semantic core of the structure with the object infinitive.

In Tatar, infinitive only indicates the action with no link to the subject. A distinctive feature of Tatar Infinitive is that it can be used in dependent and independent functions. Dependent infinitive is used in the pre- position to dependent word- белерга тели (wants to know). Independent infinitive - укыгач - күчереп алырга (After reading you are to copy the text) Independent Infinitive is mostly used in the Imperative Mood.

Әлфия эшкә керергә килде. -. Alfiya came to get a job (adverbial modifier of purpose).

Сәнгать мәктәбендә рәсем ясарга, биергә һәм ж⿻ырларга өйрәтәләр. -In art school they teach you to draw, dance and sing (object). 


\section{Мансурнын университетта укырга теләге бар. -Mansour wants to study at the university (attribute).}

\section{Results}

Thus, having considered infinitive in the English and Tatar languages we came to the following conclusions:

1) In the both languagese infinitive possesses both features of a noun and a verb. The similarity of English and Tatar infinitive with a noun is that the non-finite form of the verb in the sentence has the same functions as the noun. The similarity of infinitive with the verb is that it possesses the category of voice.

2) In the English and in the Tatar languages infinitive has a distinctive, peculiar formal marker. So the formal marker of Infinitive in English is pre-infinitive particle to, which distinguishes it from homonymous finite forms of the verb, while the formal marker of Infinitive in Tatar is the affix - bıрza, which is formed from the participle ending in -blp with the help of additive affix -za. In Tatar - affix bıpza is added to all verbs, without exception, whereas in the English language there are some words which are not followed by the particle to (and after the modal auxiliary verbs after verbs make, let, know, etc.): $\underline{\text { to }}$ run- чабырга, to tell- сөйләргә.

3) A distinctive feature of infinitive in the English and Tatar languages is that in the English language the negative form of infinitive is formed by adding the particle not, which is placed before the infinitive, while in the

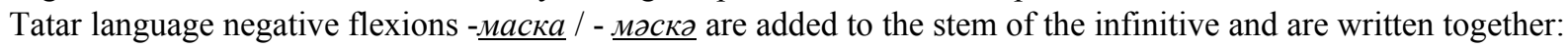
Not to go - бармаска, not to tell - сөйламаска.

\section{Discussions}

In recent years, one can observe an increased interest in infinitive and infinitive constructions. E.I. Martynova (2000) studied the origin and a linguistic nature of infinitive. M.Z. Zakiev (1993), O.M Chupasheva (1999), A.M. Konyashkin (2000), V.M. Glukhih (2002) studied syntactic functions of the infinitive. O.N. Zhuravleva (1999, 2001) studied the use of infinitive with certain groups of verbs.

Despite interest in infinitive and infinitive constructions, the real problem remains insufficiently studied. Thus, infinitive constructions need more profound and complete consideration, due to the fact that there are not so many works devoted to the subject in scientific literature. Moreover, there are no special researches on contrastive-comparative study of English and Tatar infinitive constructions in linguistic literature. This provides the necessity for contrastive-comparative examination of infinitive constructions in the English and Tatar languages and is the significance of the present study.

\section{Conclusion}

The study of infinitive structures in terms of morphology in comparative aspect in the English and Tatar languages provides an opportunity for a more detailed description and comparison of infinitives in both languages, the practical value of the study is that the results can be useful in language learning and teaching, theory and practice of translation; the study makes a significant contribution to the theory of Comparative Linguistics. It presents the first experience of complex study of key aspects of semantic and morphological and syntactic features of infinitives in both languages. The academic novelty is that the issue has not been studied previously in terms of the functioning of the English infinitive forms and their translation into Tatar. A comparative approach to the system of the English and Tatar languages is required in both theoretical and practical purposes.

The results and conclusions of the study can intensify teaching and learning of verbals in Tatar schools, innovative schools, colleges and universities. The results of the study provide an opportunity for development of a reasonable method of teaching English in Tatar schools, teaching the general and special courses on the Tatar and English languages; the results can be used in the preparation of special courses and seminars on the morphology and syntax of the English and Tatar languages.

The identification of differences and similarities of the languages helps to overcome linguistic interference; provides avoiding typical errors that occur in connection with the translation of the patterns of the native language into a foreign language.

The practical significance of the study is related to the possibilities of the use of its results in teaching of English and Tatar as a foreign language; in the theory of translation; in courses of comparative linguistics.

\section{Recommendations}

The results of the study provide an opportunity for development of a reasonable method of teaching English in Tatar schools, teaching the general and special courses on the Tatar and English languages; the results can be used in the preparation of special courses and seminars on the morphology and syntax of the English and Tatar languages. 


\section{Acknowledgments}

This work was funded by the subsidy allocated to Kazan Federal University for the state assignment in the sphere of scientific activities.

\section{References}

Admoni, V. G. (1964). Osnovy teorii grammatiki. Moscow: Nauka.

Arakin, V. D. (1989.) Tipologiya yazykov I problema metodicheskogo prognozirovaniya. Moscow: Vysshaya shkola.

Barhudarov, L. S. (1966). Struktura prostogo predlozheniya sovremennogo angliyskogo yazyka. Moscow: Vysshaya shkola.

Bayramova, L. K. (1997). Sopostavitelniy sintaksys russkogo I tatarskogo yazyko. Zelenodolsk: Delo.

Bondarko, A. V. (1971). Grammaticheskaya kategoriya I kontekst. Leningrad: Nauka.

Chupasheva, O. M. (1999). Opredelyaem sintaksicheskuyu funktsiyu infinitiva. Moscow: Russkaya rech.

Gatiatullina, Z. Z. (1979). Sravnitelnaya tipologiya rodnogo (tatarskogo) i angliyskogo yazikov: Kurs lekciy. Kazan: KGPI.

Glukhih, V. M. (2002). Infinitive kak chlen predlozheniya (Material dlya sintaksicheskogo razbora v pedvuze). Russkiy yazyk $v$ shkole, 4, 95-99.

Guhman, M. M. (1968). Grammaticheskaya kategoriya I structura paradigm. Issledovaniya po obschey teorii grammatiki. Moscow: Nauka.

Khisamova, V. N. (2004). Glagolnaya systema tatarskogo i angliyskogo yazikov. Kazan: Kazan. gos. univ.

Konyashkin, A. M. (2000). Semantiko-sintaksicheskaya priroda infinitiva I problema infinitivnogo podlezhaschego $\mathrm{v}$ sintaksicheskih issledovaniyah. Vestnik Hakasskogo gosudarstvennogo universiteta (pp.87-90), Abakan: Yazykoznanie.

Moiseev, A. I. (1952). Upotreblenie zavisimogo infinitiva $v$ sovremennom russkom yazyke: avtoref.dis.kand.filol.nauk: 10.02.01. Leningrad: Uchpedgiz.

Potebnya, A. A. (1958). Iz zapisok po russkoy grammatike. Moscow: Prosveschenie.

Ramazanova, D. B. (1974). Grammaticheskiye osobennosty govora permskih tatar. Materiali po tatarskoy dialectologii, 3, 92-112. Kazan.

Salekhova, N. Kh. (1984). Sravnitelnaya typologiya vremennoy systemy nemeckogo I tatarskogo yazikov: Kurs lekci. Kazan: Tatar.knizh. izd-vo.

Shahmatov, A. A. (1941). Sintaksis russkogo yazyka. Leningrad: Uchpedgiz.

Tumasheva, D. G. (1986). Tatarskiy glagol: Opit funkcionalno-semanticheskikh issledovaniy grammaticheskikh kategoriy: Ycheb.posobiye. Kazan: Izd-vo KGU.

Vinogradov, V. V. (1972). Russkiy yazyk (grammaticheskoe uchenie o slove) (2nd ed.). Moscow: Vysshaya shkola.

Zakiyev, M. Z. (1992). Tatarskaya grammatical v.3.Syntaksis. Kazan: Tatar.knizh. izd-vo.

Zakiyev, M. Z. (1993). Tatarskaya grammatical v.2.Morphologiya. Kazan: Tatar.knizh. izd-vo.

Zhuravlyova, O. N. (2001). Semantika kauzativnyh glagolov sochetayuschihsya s tselevym infinitivom. Kirov.

\section{Copyrights}

Copyright for this article is retained by the author(s), with first publication rights granted to the journal.

This is an open-access article distributed under the terms and conditions of the Creative Commons Attribution license (http://creativecommons.org/licenses/by/3.0/). 